\title{
Effects of radioactive contamination on plant populations and radiological protection of the environment
}

\author{
S. Geras'kin, A. Oudalova, N. Dikareva, E. Mozolin, J. Vanina, \\ T. Baykova and V. Dikarev
}

Russian Institute of Agricultural Radiology and Agroecology, 249020 Obninsk, Russia

\begin{abstract}
Data from large scale field experiments are clearly highly relevant to the development of a new system for radiological protection of the environment. Therefore, an actuality and severity of population-level effects within radioactively contaminated areas are among key problems today. The results of long-term field studies in the Bryansk Region, Russia, affected by the Chernobyl accident, and at the Semipalatinsk Test Site, Kazakhstan are discussed. The results of these studies clearly indicate that plant populations growing in areas with relatively low levels of pollution are characterized by the increased level of both cytogenetic disturbances and genetic diversity. Genetic processes in exposed populations lead to increasing of phenotypic diversity and rapid selection of novel phenotypes favoured in changed environment. In particular, radioactive contamination of the plants' environment activates genetic mechanisms, changing a population's resistance to exposure. However, in different radioecological situations, genetic adaptation to extreme edaphic conditions in plant populations could be achieved with different rates. Such evolutionary effects are of special concern because they are able to negatively affect population dynamics and local extinction rates. A development of a system for protection of the environment from ionizing radiation should be based on a clear understanding of these effects and their contribution to biological response.
\end{abstract}

\section{INTRODUCTION}

Studies to examine biological effects on non-human biota in natural settings provide a unique opportunity for obtaining information about the potential biological hazard associated with radioactive contamination. Nevertheless, up to now there is a distinct lack of quantitative data [1] on the real longterm biological consequences of chronic radiation exposure lasting a long period of time, in particular, at the population level. Actually, very few studies exist that are directly relevant to understanding the responses of plant and animal populations to radionuclides in their natural environments. These data gaps imply that the protection of the environment from ionizing radiation will require more experimental data related to effects of chronic low-level exposure to radioactive contaminants at the population level.

\section{RESULTS}

The majority of abiotic stress studies performed under controlled conditions in the laboratory does not reflect the actual situation that occur in the field. Therefore, to understand effects of contaminant exposure on plant populations properly we must pay attention to what is actually going on in the field. On the other hand, radiation effects are not always easy to separate from modifications caused by other factors. Radiation interacts with other form of stress, which reduces considerably our ability to predict effects on natural systems. Although radionuclides cause primary damage at the molecular level, there are emergent effects at the level of populations, non-predictable solely from the knowledge of elementary mechanisms of the pollutants' influence. Therefore, a well-directed accumulation of knowledge is needed, and appropriate experimental data analysis is necessary. Previously completed and ongoing field studies on biological effects in different species of wild and agricultural plants are briefly 
summarized in Table 1. It is easy to see that these experiments cover a wide range of radioecological situations and climatic zones.

Table 1. Field studies on wild and agricultural plants.

\begin{tabular}{|c|c|c|}
\hline Species & Site \& Time & Assay and/or endpoints \\
\hline $\begin{array}{l}\text { Winter rye and } \\
\text { wheat, spring } \\
\text { barley and oats }\end{array}$ & $\begin{array}{l}\text { 10-km ChNPP zone }\left(11.7-454 \mathrm{MBq} / \mathrm{m}^{2}\right) \text {, } \\
\text { 1986-1989 }\end{array}$ & $\begin{array}{l}\text { Morphological indices of seeds viability } \\
\text { cytogenetic disturbances in intercalar and } \\
\text { seedling root meristems [2] }\end{array}$ \\
\hline $\begin{array}{l}\text { Scots pine, couch- } \\
\text { grass }\end{array}$ & $\begin{array}{l}\text { 30-km ChNPP zone, }(250-2690 \mu \mathrm{R} / \mathrm{h}) \text {, } \\
1995\end{array}$ & $\begin{array}{l}\text { Cytogenetic disturbances in seedling root } \\
\text { meristem [3] }\end{array}$ \\
\hline Scots pine & $\begin{array}{l}\text { Radioactive waste storage facility, } \\
\text { Leningrad Region, Russia, 1997-2002 }\end{array}$ & $\begin{array}{l}\text { Cytogenetic disturbances in needles } \\
\text { intercalar and seedling root meristems [4] }\end{array}$ \\
\hline Wild vetch & $\begin{array}{l}\text { Radium production industry storage cell, } \\
\text { Komi Republic, Russia, (73-3300 } \mu \mathrm{R} / \mathrm{h} \text { ), } \\
\text { 2003-2007 }\end{array}$ & $\begin{array}{l}\text { Embryonic lethals, cytogenetic disturbances } \\
\text { in seedling root meristem [5] }\end{array}$ \\
\hline Scots pine & $\begin{array}{l}\text { Sites in the Bryansk Region } \\
\text { radioactively contaminated in the } \\
\text { Chernobyl accident }\left(451-2344 \mathrm{kBq} / \mathrm{m}^{2}\right) \text {, } \\
2003-2007\end{array}$ & $\begin{array}{l}\text { Cytogenetic disturbances in seedling root } \\
\text { meristem, enzymatic loci polymorphism } \\
\text { analyses [6] }\end{array}$ \\
\hline $\begin{array}{l}\text { Crested hairgrass, } \\
\text { crested wheatgrass }\end{array}$ & $\begin{array}{l}\text { Semipalatinsk Test Site, Kazakhstan, } \\
(74-3557 \mu \mathrm{R} / \mathrm{h}), 2005-2007\end{array}$ & $\begin{array}{l}\text { Cytogenetic disturbances in coleoptiles of } \\
\text { germinated seeds }\end{array}$ \\
\hline
\end{tabular}

Forest trees have gained much attention in recent years as nonclassical model eukaryotes for population, evolutionary and ecological studies [7]. The low domestication, large open-pollinated native populations and high sensitivity to environmental exposure make conifers almost ideal species for the study of environmental effects of radioactive contamination. In Fig. 1, the results of long-term observations on Scots pine populations growing in the Bryansk Region radioactively contaminated as a result of the Chernobyl accident are presented. The results of these experiments indicate that cytogenetic disturbances frequency in the affected populations is significantly higher than in the reference populations during the whole four-year observation period. Compiled with data from other our studies $[2,4]$, these findings indicate that an increased level of cytogenetic disturbances is a typical phenomenon for plant populations growing in areas with relatively low levels of pollution.

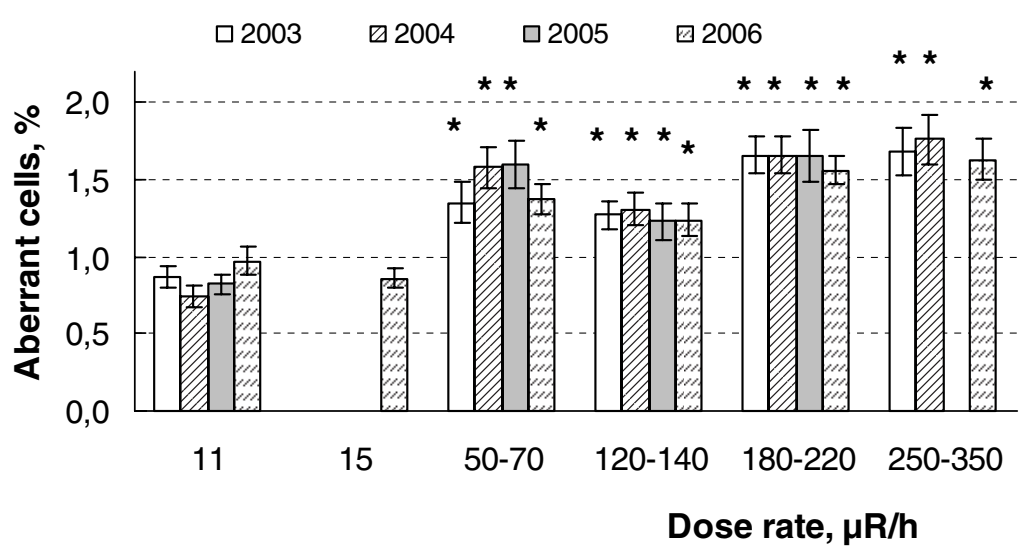

Figure 1. Aberrant cells in root meristem of germinated seeds from Scots pine populations, the Bryansk Region, Rusia, 2003-2006. * - significant difference from the reference population $\mathrm{p}<0.05$.

With each passing year since the Chernobyl accident of 1986, more questions arise [8] about the potential for organisms to adapt to radiation exposure. The detection of cytogenetic disturbances applied 
in our studies might only be tip of an iceberg, reflecting global structural and functional rearrangements induced by radiation in exposed populations. Alterations in the genetic make-up of populations are of primary concern because somatic changes, even if they lead to a loss of individuals, will not be critical in populations with a large reproductive surplus. To analyze whether exposure to radionuclides causes changes in population genetic structure, we evaluated frequencies of three different types of mutation (null allele, duplication and changing in electrophoretic mobility) of enzymatic loci in endosperm and embryos of pine trees from the studied populations. It is found that chronic radiation exposure results in the significant increase of total occurrence of enzymatic loci mutations (Fig. 2). Mutation is one of mechanisms that maintains genetic variation within a population and thus enables that population to cope with an adversely changing environment. This may speed up adaptation and microevolution under adverse environmental conditions. Indeed, an average number of phenotypes in the exposed pine trees populations, estimated via the Zhivotovskiy index calculation for the number of alleles at endosperm analysis, significantly exceeds the control level and increases along with a dose absorbed by generative organs of pine trees (Fig. 3). A decrease in heterozygosity within individuals has been associated [9] with decreased resistance to diseases, decreased growth rates, and decreased fertility. This would suggest that variations in individual heterozygosity may affect population growth and recruitment. It is apparent from the data presented (Fig. 4) that the observed heterozygosity in pine trees populations at the radioactively

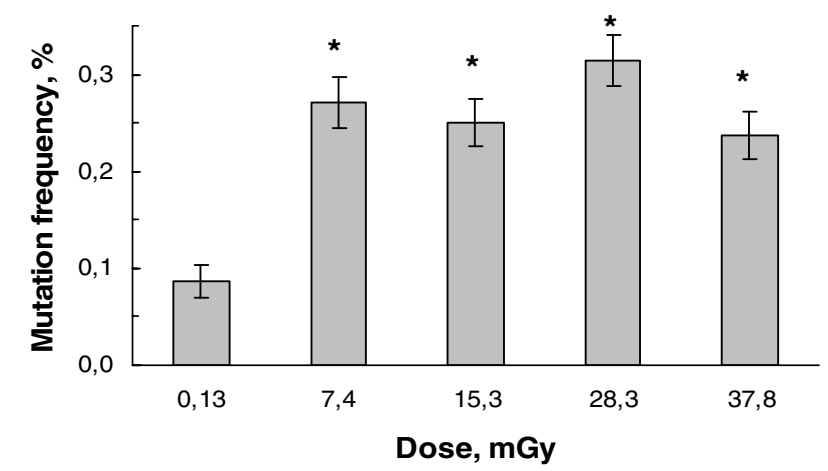

Figure 2. Mutation frequency of enzymatic loci in embryos from Scots pine populations, the Bryansk Region, Russia, in dependence on dose absorbed by generative organs of pine trees. * - significant difference from the reference population, $\mathrm{p}<0.05$.

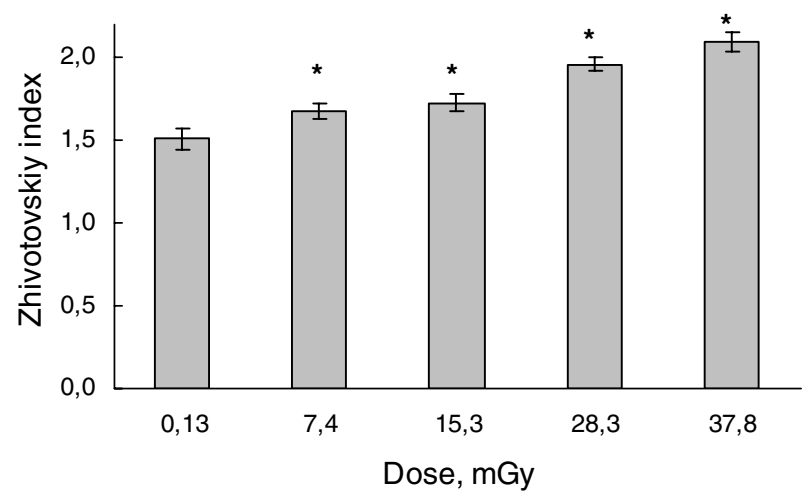

Figure 3. Zhivotovskiy index calculated for Scots pine populations, the Bryansk Region, Russia, 2003-2006 in dependence on dose absorbed by generative organs of pine trees. ${ }^{*}$ - significant difference from the reference population, $\mathrm{p}<0.05$. 


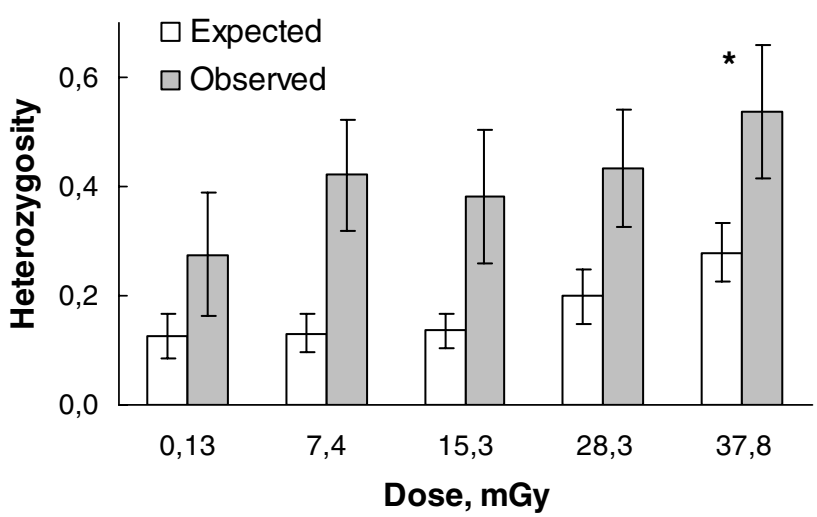

Figure 4. Heterozygosity in endosperms of Scots pines growing in the Bryansk Region, Russia 2003-2006 in dependence on dose absorbed by generative organs of pine trees. ${ }^{*}$ - significant difference from the reference population, $\mathrm{p}<0.05$.

contaminated sites is essentially higher than the expected one. This could mean that in the affected populations, there is a natural selection in favor of heterozygotes. Information on specific functions connected with isoenzymes is scarce. We can, nevertheless, conclude that the relationship between radioactive contamination and genetic divergence provides evidence of adaptation which optimizes the physiological response of a population to environmental changes. Keeping in mind all the data mentioned, it could be concluded that genetic processes in the exposed populations lead to increasing of phenotypic diversity and rapid selection of novel phenotypes favoured in changed environment.

In the Semipalatinsk Test Site, 116 air and ground-surface explosions for nuclear and hydrogen bomb testing were carried out in 1949-1963. An ongoing study of crested hairgrass (Koeleria gracilis Pers.) populations, a typical wild crop for Kazakhstan, has shown that the frequency of cytogenetic disturbances in coleoptiles of germinated seeds increases proportionally to the dose absorbed by plants during vegetation period (Fig. 5). The agreement between findings from two years of study, different in weather conditions, suggests the leading role of radioactive contamination in an occurrence of cytogenetic effects. At the explosions epicenter (EF2 site), frequencies of all types of cytogenetic disturbances (excluding chromatid aberrations in 2005) significantly exceed the corresponding level

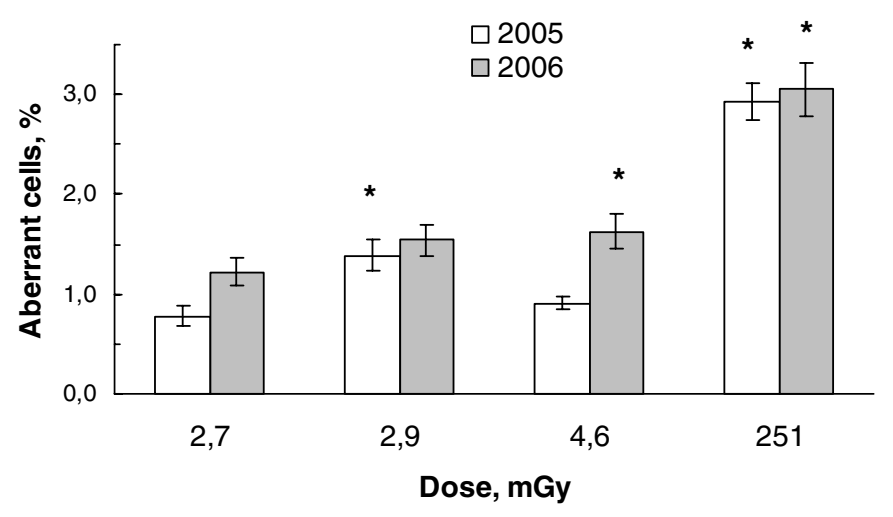

Figure 5. Frequency of aberrant cells in coleoptiles of germinated seeds of crested hairgrass collected in the Semipalatinsk Test Site, Kazakhstan in 2005-2006 in dependence on annual dose absorbed. * - significant difference from the corresponding control, $\mathrm{p}<0.05$. 
in the reference EF3 site (Fig. 6). Severe disturbances of single and double bridges and laggard chromosomes contribute mainly to the observed cytogenetic effect.
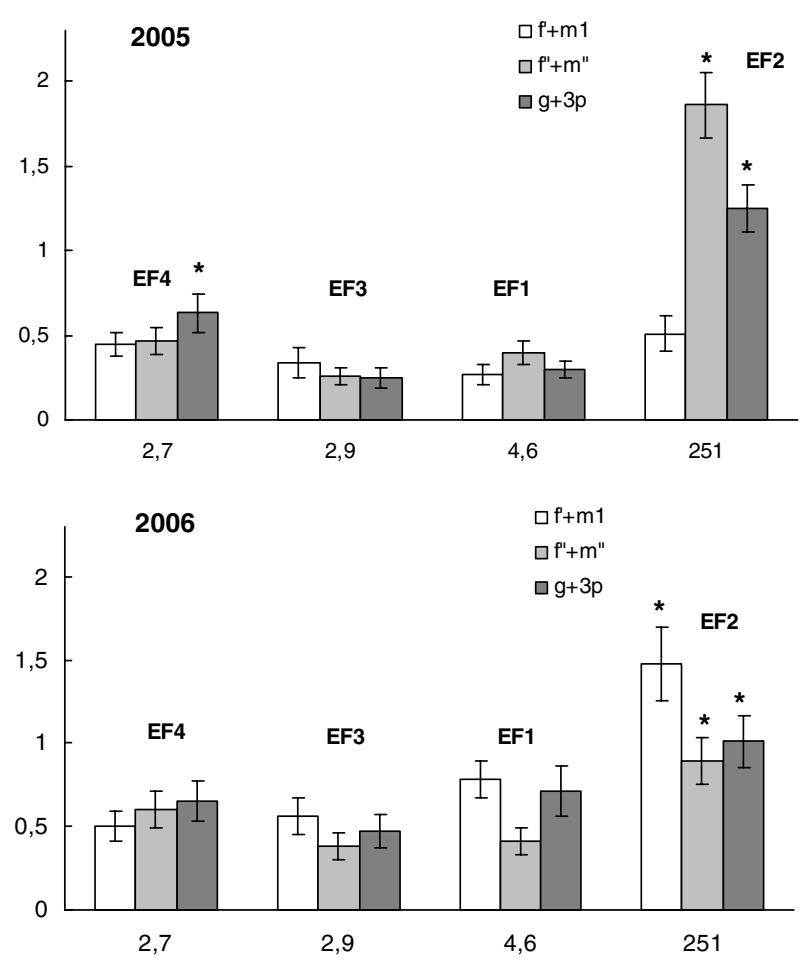

Figure 6. Spectrum of cytogenetic disturbances $\left(10^{-2}\right)$ in coleoptiles of germinated seeds of crested hairgrass, the Semipalatinsk Test Site, Kazakhstan, 2005-2006 in dependence on annual dose absorbed. $\mathrm{f}^{\prime}, \mathrm{m}^{\prime}-$ chromatid (single) fragments and bridges; $\mathrm{f}^{\prime \prime}, \mathrm{m}^{\prime \prime}$ - chromosome (double) fragments and bridges; $\mathrm{g}$ - lagging chromosomes; $3 p$ - tripolar mitoses; * - significant difference from the corresponding reference level (EF3), $p<0.05$.

\section{CONCLUSIONS}

Data from large scale field experiments are clearly highly relevant to the development of a new system for radiological protection of the environment. Therefore, an actuality and severity of population-level effects within radioactively contaminated areas are among key problems today. The results described here clearly indicate that plant populations growing in areas with relatively low levels of pollution are characterized by the increased level of both cytogenetic disturbances and genetic diversity. Man-made pollution may influence an evolution of exposed populations through a contaminant-induced selection process. Genetic processes in exposed populations leads to an increase in phenotypic diversity and rapid selection of novel phenotypes favoured in changed environment. In particular, radioactive contamination of the plants' environment activates genetic mechanisms, changing a population's resistance to exposure. However, in different radioecological situations, genetic adaptation to extreme edaphic conditions in plant populations could be achieved with different rates [5]. These processes have a genetic basis; therefore, understanding changes at the genetic level should help in identifying more complex changes at higher levels. Such evolutionary effects are of special concern because they are able to negatively affect population dynamics and local extinction rates. A development of a system for radiation protection of the environment should be based on a clear understanding of these effects and their contribution to biological response. This should be addressed in the future. 


\section{Acknowledgments}

This work was partly supported by ISTC projects no. 3003 and K-1328 as well as Ministry of Atomic Energy of Russian Federation (state contracts no. 1.30.04.16/7, no. 1.30.05.16/7, no. 1.30.06.16/7, P-025/1 and 5-18(359)-31802) and Russian Foundation for Basic Research (grant 08-0695/04).

\section{References}

[1] Garnier-Laplace J., Gilek M., Sundell-Bergman S. and Larsson C.M., J. Radiological Protection 24 (2004) 139-155.

[2] Geras'kin S.A., Dikarev V.G., Zyablitskaya Ye.Ya., Oudalova A.A., Spirin Y.V. and Alexakhin R.M., J. Environmental Radioactivity 66 (2003) 155-169.

[3] Geras'kin S.A., Zimina L.M., Dikarev V.G., Dikareva N.S., Zimin V.L., Vasiliyev D.V., Oudalova A.A., Blinova L.D. and Alexakhin R.M., J. Environmental Radioactivity 66 (2003) 171-180.

[4] Geras'kin S.A., Kim J.K., Oudalova A.A., Vasiliyev D.V., Dikareva N.S., Zimin V.L. and Dikarev V.G., Mutation Research 583 (2005) 55-66.

[5] Evseeva T.I., Majstrenko T.A., Geras'kin S.A. and Belych E.S., Radiat. Biol. Radioecol. 47 (2007) 54-62 (in Russian).

[6] Geras'kin S.A., Dikareva N.S., Oudalova A.A., Spiridonov S.I. and Dikarev V.G., Radiat. Biol. Radioecol. 48 (2008) (in Russian).

[7] Gonzalez-Martinez S.C., Krutovsky K.V. and Neale D.B., New Phytologist 170 (2006) 227-238.

[8] Geras'kin S.A., Fesenko S.V. and Alexakhin R.M., Environment International 34 (2008).

[9] Theodorakis C.W., Ecotoxicology 10 (2001) 245-256. 